\title{
ZINC INCREASES THE EFFECTS OF ESSENTIAL AMINO ACIDS-WHEY PROTEIN SUPPLEMENTS IN FRAIL ELDERLY
}

\author{
A. RODONDI, P. AMMANN, S. GHILARDI-BEURET, R. RIZZOLI
}

\begin{abstract}
Division of Bone Diseases [WHO Collaborating Center for Osteoporosis Prevention], Department of Rehabilitation and Geriatrics, University Hospitals and Faculty of Medicine of Geneva, CH - 1211 Geneva 14, Switzerland. Address for correspondence: Patrick Ammann, M.D. Division of Bone Diseases, Department of Rehabilitation and Geriatrics, University Hospitals and Faculty of Medicine of Geneva, CH - 1211 Geneva 14 (Switzerland), Phone: (41-22) 372 99 50, Fax: (41-22) 382 99 73, E-mail: Patrick.Ammann@unige.ch
\end{abstract}

\begin{abstract}
Protein undernutrition is frequent in the elderly. It contributes to the development of osteoporosis, possibly via lower IGF-I. Dietary zinc can influence IGF-I production. Objectives: To determine the influence of dietary zinc addition on IGF-I and bone turnover responses to essential amino acids-whey (EAA-W) protein supplements in frail elderly. Design and setting: A daily oral protein supplement was given to hospitalized patients for 4 weeks. On a randomized, double-blind basis, patients received either an additional $30 \mathrm{mg} / \mathrm{day}$ of zinc or control. Participants: Sixty-one hospitalized elderly aged 66.7 to 105.8 , with a mini-nutritional assessment score between 17 and 24 were enrolled. Measurements: Activities of daily living; dietary intakes; serum IGF-I, IGF-BP3, CrossLaps ${ }^{\mathrm{TM}}$, osteocalcin and zinc were measured before and after 1, 2 and 4 weeks of protein supplementation. Results: Serum IGF-I rapidly increased in both groups. Zinc accelerated this increase with changes of $+48.2 \pm 14.3$ and $+22.4 \pm 4.7 \%(\mathrm{p}<.05)$ by 1 week, in the zinc-supplemented and control groups, respectively. Zinc significantly decreased the serum bone resorption marker CrossLaps ${ }^{\mathrm{TM}}$ by already 1 week. Activities of daily living improved by $+27.0 \pm 3.1$ and $+18.3 \pm 4.5 \%$ in zinc-supplemented and control groups, respectively.Conclusion: In the elderly, zinc supplementation accelerated the serum IGF-I response to EAA-W protein by 1 week and decreased a biochemical marker of bone resorption.
\end{abstract}

Key words: Osteoporosis, fracture, bone remodeling, nutrition, ageing.

\section{Introduction}

Undernutrition, particularly protein deficiency, is often encountered in the elderly population $(1,2)$. Whilst a reduction in caloric intake may accompany the decrease in energy expenditure in the elderly, it appears that sufficient protein intakes are mandatory for bone health (3). A concurrent reduction of dietary protein with aging could be detrimental for the preservation of bone integrity. A variety of cross-sectional and longitudinal studies have shown a positive association between bone mineral mass and dietary protein intake (4-8). Dietary proteins influence both the production and action of IGF-I and thereby the effect of IGF-I on bone anabolism $(3,9$, 10). In preclinical studies, an isocaloric low protein diet decreases areal bone mineral density (BMD) at the levels of skeletal sites formed by trabecular and cortical bone $(11,12)$, alters trabecular microarchitecture, renders bone cortices thinner (13) and modifies intrinsic bone tissue quality as evaluated by a nanoindentation test (14). These various changes result in a decrease of bone strength. In humans, these alterations could contribute to an increased fracture risk $(3,15)$.

In terms of molecular mechanisms, an isocaloric low protein diet is associated with increased bone resorption and decreased bone formation, reduced IGF-I production, and an accompanying resistance of bone to the effects of both IGF-I and growth hormone $(16,17)$. An altered gonadotrop axis in both males and females has also been documented $(11,12)$. The bone catabolic effects of an isocaloric low protein diet seem to be a TNF-alpha-dependent process (18).
Protein repletion corrects the alterations caused by protein undernutrition. Indeed, in elderly patients with a recent hip fracture, protein supplements decrease the rates of medical complications $(19,20)$, reduce accelerated bone loss $(21,22)$, and lower the duration of stay in rehabilitation care facilities by $25 \%$ (21). These observations have been associated with an increase in circulating serum IGF-I levels. In preclinical studies, isocaloric essential amino acid supplements correct bone mechanical properties by improving microarchitecture (connectivity and cortical thickness), and intrinsic bone tissue quality $(13,14)$. The correction of protein deficiency also reverses the alterations in both the somatotrop and gonadotrop axes, and in bone remodeling.

Zinc is known to play a role in IGF-I production $(23,24)$. Circulating levels of IGF-I increase with dietary zinc supplementation $(25,26)$. Growth retardation related to zinc deficiency is associated with low serum IGF-I concentrations, inhibition of the anabolic actions of IGF-I (27) and with a decreased expression of the IGF-I and GH receptor genes (27, 28). A meta-analysis of 25 studies investigating the effects of zinc supplementation on growth in prepubertal children showed a highly statistically significant effect on linear growth and weight gain (29). On the other hand, decreased zinc reserves are observed in undernourished subjects $(30,31)$. The presence of zinc inhibits the stimulatory effect of regucalcin, a regulatory protein involved in intracellular signalling on osteoclast-like cell formation (32). Several studies have shown that zinc has a distinct effect on bone metabolism by inhibiting bone resorption and stimulating bone formation (32-36). 


\section{ZINC AND PROTEIN SUPPLEMENTS}

The relationship between zinc status and IGF-I in the elderly has not been established, although the correlation between serum IGF-I concentrations and zinc intake was significantly better than that with protein intake or age in a group of healthy community-dwelling post-menopausal women (24).

In the present study, we assessed the effect of zinc supplements on circulating IGF-I levels, bone remodeling and physical performance responses to protein repletion in undernourished, elderly patients. The results indicate that zinc supplementation accelerates the serum IGF-I response to essential amino acids-whey protein administration, and is associated with a decrease in the serum levels of a biochemical marker of bone resorption and improved functional performance.

\section{Patients and methods}

\section{Patients}

Within one week after admission to a tertiary care geriatric hospital, elderly patients of both sexes were recruited between October 1999 and August 2001. Admissions were due to cardiovascular and lung diseases $(27 \%)$, osteoarticular disorders (16\%), infections (13\%), neurological diseases (10\%), falls, psychiatric disorders or skin diseases (34\%). Inclusion criteria consisted of ability to give a written, informed consent and a mini nutritional assessment score between 17 and 24 (corresponding to a failure to thrive category) (37). Exclusion criteria were: severely decompensated cardiac, pulmonary, renal (creatinine clearance $<30 \mathrm{ml} / \mathrm{min}$ ) or hepatic failure; major mental impairment (minimal mental state score $<17$ ), urine incontinence, inflammatory syndrom (C-reactive protein $>15 \mathrm{mg} / \mathrm{l})$, bedridden, corticosteroids at a dose greater than 7.5 $\mathrm{mg} /$ day prednisone-equivalent, life expectancy estimated as shorter than one month. All patients were given a daily $20 \mathrm{~g}$ oral protein supplement containing $15 \mathrm{~g}$ whey protein and $5 \mathrm{~g}$ essential amino acids (in a proportion similar to that found in casein), and 550mg calcium (provided by Novartis Nutrition, Berne, Switzerland). The protein supplement was administered in the evening preferentially, or fractionated throughout the day, for a period of 4 weeks. Using a random number table, the patients were assigned to $30 \mathrm{mg} /$ day oral zinc directly added to the protein supplements powder, or no addition, on a strict double-blind basis. Non compliance was defined by consumption of less than $50 \%$ of the powder. The patients were stratified into two arms according to baseline serum albumin levels, with a limit between strates of $30 \mathrm{~g} / \mathrm{l}$ in a fully hydrated state. A group of 8 patients fulfilling the same inclusion and exclusion criteria, but who did not want to participate in an intervention study, were followed at a 4-week interval.

\section{Clinical data}

We evaluated clinical status, dietary intakes, activities of daily living (38) and medical treatments at baseline (within one week after admission), and after 1, 2 and 4 weeks of nutritional supplementation. Compliance, incidence of medical complications and side effects of treatment (diarrhea, nausea), and length of hospital stay were recorded.

\section{Biochemical analysis}

Fasting venous blood and second voiding urine samples were collected at baseline, and after 1, 2 and 4 weeks of nutritional supplements. Radioimmunoassays, immunoradiometric assays and enzyme-linked immunoassay were used to measure calcidiol (Incstar Corp, Stillwater, MN), intact parathormone (Nichols institute, San Juan Capistrano, CA), IGF-I after acid-ethanol extraction (Nichols institute, San Juan Capistrano, CA), IGF-binding protein-3 (DSL, Webster, Texas), osteocalcin (Cis-Bio, Gif-sur-Yvette, France), and CrossLaps ${ }^{\mathrm{TM}}$ (Roche-diagnostic, Lucerne, Switzerland). Calcitriol was determined using a protein-binding assay (Incstar Corp, Stillwater, MN). Albumin, protein, total calcium, phosphate, creatinine and C-reactive protein were measured using routine laboratory methods. Ionized calcium was measured using a specific electrode. Zinc was determined using the Randox colorimetric method (automate COBAS INTEGRA 700, Roche-diagnostic). Differential white cell counts were determined at weeks $0,1,2$, and 4 . Renal tubular transports of calcium and phosphate were measured with fasting serum and urine values, using nomograms as previously described (39, $40)$.

\section{Statistical analysis}

Values are means \pm SEM. Level of significance was evaluated using an unpaired two-tailed student t-test, when two groups were compared, an ANOVA for repeated measurements was used to evaluate evolution over time and a Wilcoxon rank test was employed as an alternative to the paired student t-test to compare two groups, when the values were not normally distributed.

\section{Results}

\section{Trial outline}

We recruited 61 patients into this randomized, double-blind trial and 8 untreated controls. During the 28-day intervention period, $14(23 \%)$ patients dropped out, 12 due to nausea, low compliance, refusal to pursue the trial at home and 2 deaths (one at home from bronchopneumonia and one in hospital from bronchoaspiration). For the final analysis, 47 patients and 5 untreated controls were available (Fig.1). Twenty-seven patients returned home before the end of the study. Blood and urine samples were collected in their private accommodation.

\section{Baseline characteristics}

$85 \%$ of enrolled patients were women and the mean age was $85.0 \pm 7.4$ years (mean $\pm \mathrm{SD}$, range: 66.7 to 105.8 ). The different diagnoses were equally distributed in both groups (data not shown). Baseline characteristics were similar in the randomized groups (Table 1). Dietary energy intake was 1228 $\pm 7.0 \mathrm{Kcal} /$ day $(5140 \mathrm{KJ})$ with $43 \pm 3 \mathrm{~g} /$ day protein, 
representing $0.77 \pm 0.03 \mathrm{~g} / \mathrm{kg} \mathrm{BW}$, with no differences between the two supplemented groups. Body mass index was significantly higher in the untreated controls. Whilst there were no differences in biochemical baseline characteristics, including zinc levels, between the patients in the randomized controlled trial and the untreated controls, the group with zinc supplements had a higher serum level of calcidiol $(\mathrm{p}=.029)$ than the group without zinc (Table 2). Except mean serum albumins which were below the lower limit of normal range, confirming the state of malnutrition of the randomized patients, all values were within the reference range.

\section{Figure 1}

Trial outline

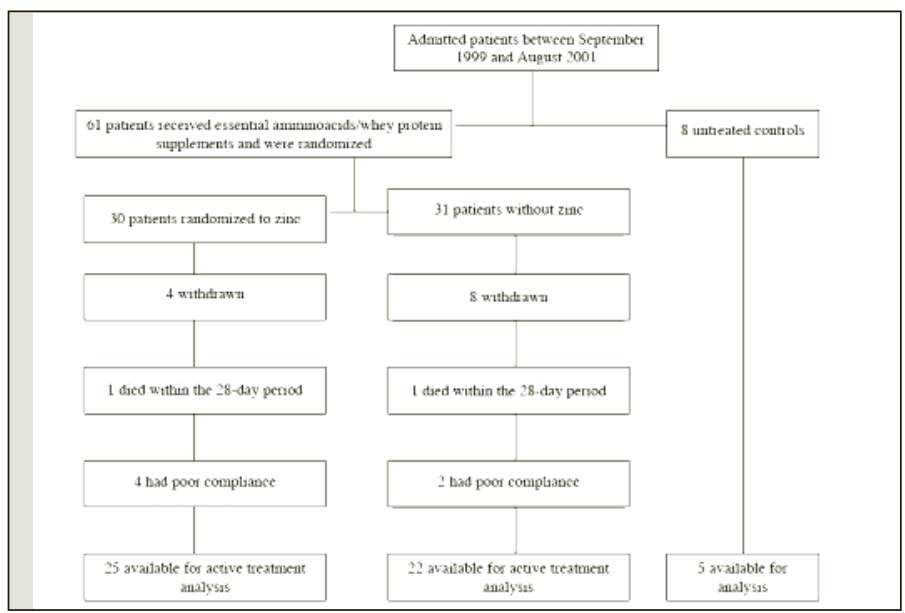

Among patients admitted into a tertiary care geriatric hospital between September 1999 and August 2001, 69 patients were included in the study (61 in the randomized, double blind trial)

Table 1

Patients Baseline Characteristics

\begin{tabular}{|c|c|c|c|c|}
\hline & $\begin{array}{c}\text { Normal } \\
\text { range }\end{array}$ & $\begin{array}{c}\text { EAA / whey } \\
\text { protein } \\
\text { with zinc } \\
(30 \mathrm{mg} / \mathbf{d}) \\
(\mathbf{n}=\mathbf{3 0})\end{array}$ & $\begin{array}{c}\text { EAA / whey } \\
\text { protein } \\
\text { without zinc } \\
(\mathbf{n}=\mathbf{3 1})\end{array}$ & $\begin{array}{c}\text { Untreated } \\
\text { controls } \\
(n=8)\end{array}$ \\
\hline Age (year) & & $83.6(1.3)$ & $86.4(1.3)$ & $85.0(2.6)$ \\
\hline $\mathrm{F} / \mathrm{M}$ & & $25 / 5$ & $27 / 4$ & $7 / 1$ \\
\hline Previous accommodationa & & $9 \quad(30 \%)$ & $13 \quad(42 \%)$ & $2(25 \%)$ \\
\hline $\begin{array}{l}\text { - private accommodation } \\
\text { - hospital }\end{array}$ & & $21(70 \%)$ & $18 \quad(58 \%)$ & $6 \quad(75 \%)$ \\
\hline Biochemistry & & & & \\
\hline $\begin{array}{l}\text { Protein -adjusted calcium } \\
(\mathrm{mmol} / \mathrm{l})\end{array}$ & $2.2-2.6$ & $2.42(0.02)$ & $2.39(0.02)$ & $2.32(0.02)$ \\
\hline Ionised calcium (mmol/l) & $1.12-1.32$ & $1.20(0.01)$ & $1.19(0.01)$ & $1.19(0.03)$ \\
\hline Phosphate (mmol/l) & $0.80-1.30$ & $1.02(0.03)$ & $1.04(0.03)$ & $1.00(0.05)$ \\
\hline Creatinine $(\mu \mathrm{mol} / \mathrm{l})$ & $45.0-98.0$ & $74.9(4.8)$ & $74.0(4.2)$ & $72.2(10.7)$ \\
\hline Albumin (g/l) & $35.0-52.0$ & $31.0(0.7)$ & $30.4(0.8)$ & $33.7(2.7)$ \\
\hline Protein $(\mathrm{g} / \mathrm{l})$ & $61.0-82.0$ & $64.4(1.0)$ & $61.9(0.8)$ & $66.8(2.5)$ \\
\hline Lymphocytes Count (G/1) & & $1.5(0.1)$ & $1.5(0.1)$ & $1.5(0.2)$ \\
\hline $\mathrm{CRP}(\mathrm{mg} / \mathrm{l})$ & $0-10$ & $8.1(1.6)$ & $11.4(2.0)$ & $3.5(1.6)$ \\
\hline $\mathrm{BRI}(\mathrm{mmol} / \mathrm{mmol})^{\mathrm{b}}$ & $0.10-0.50$ & $0.44(0.07)$ & $0.50(0.06)$ & $0.42(0.15)$ \\
\hline $\mathrm{TmPi} / \mathrm{GFR}(\mathrm{mmol} / \mathrm{l} \mathrm{GFR})^{\mathrm{c}}$ & $0.80-1.35$ & $0.97(0.04)$ & $0.99(0.05)$ & $1.03(0.12)$ \\
\hline TRCaI $(\mathrm{mmol} / \mathrm{l} \mathrm{GFR})^{\mathrm{d}}$ & $2.40-2.90$ & $2.67(0.03)$ & $2.61(0.04)$ & $2.60(0.07)$ \\
\hline
\end{tabular}

Values are given as the mean (SEM), except for the previous accommodation. EAA = Essential amino acids. a. Values are given as the absolute number (percentage); b. Bone Resorption Index (BRI) is the fasting urinary calcium-to-creatinine ratio taken as a reflection of net bone resorption; c. Renal tubular reabsorption of phosphate; d. Renal tubular reabsorption of calcium index.
Effects of zinc and / or essential amino acids-whey protein supplements on plasma IGF-I

Zinc levels increased by $57.5 \%$ (percent change from baseline) in the zinc-supplemented group after 28 days (Table 2). IGF-I levels decreased in the untreated controls during the 4-week observation period. In contrast, IGF-I rapidly increased in the two groups with essential amino acids-whey protein supplementation $(\mathrm{p}=.0001)$ reaching a plateau by only the second week of supplementation (Fig. 2). The addition of 30 $\mathrm{mg}$ /day of zinc accelerated the steep elevation of serum IGF-I, compared to the group without zinc, with a response significantly higher at week $1(\mathrm{p}=.027)$. At 4 weeks, there was no difference with or without zinc addition. IGF binding protein 3 concentrations remained constant, so that IGF-I to IGF binding protein 3 ratio exhibited kinetics similar to that of IGF-I alone which reflects hormone bioactivity (Table 2) (41).

Figure 2

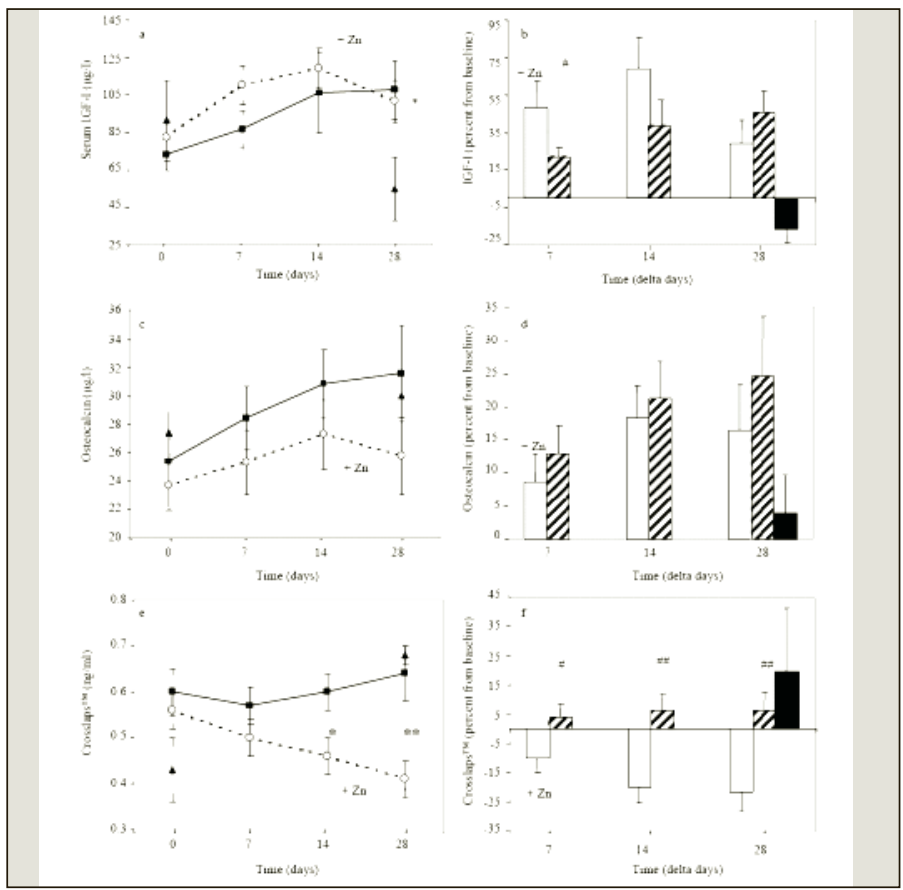

a) b) Effects of zinc addition on the IGF-I response to essential amino acids-whey protein supplements. The results are means SEM [absolute values a) and percent from baseline b)] and were obtained after 1,2 and 4 weeks of nutritional supplements containing $20 \mathrm{~g}$ of protein $(15 \mathrm{~g}$ whey protein and $5 \mathrm{~g}$ of essential amino acids) without zinc (a: closed squares; b: stippled columns) or with zinc (a: open squares; b: open columns). Untreated controls are represented by triangles (a) and filled columns (b). \# p $=0.0001$ : ANOVA for repeated measures; there is a significant increase overtime in both groups receiving amino acidswhey protein; $* \mathrm{p}<0.05$ vs controls without zinc.

c) d) Effects of zinc addition on the serum osteocalcin response to essential amino acidswhey protein supplements. The results are means SEM [absolute values c) and percent from baseline d)] and were obtained after 1,2 and 4 weeks of nutritional supplements containing $20 \mathrm{~g}$ of protein ( $15 \mathrm{~g}$ whey protein and $5 \mathrm{~g}$ of essential amino acids) without zinc (c: closed squares; d: stippled columns) or with zinc (c: open squares; d: open columns). Untreated controls are represented by triangles (c) and filled columns (d). e) f) Effects of zinc addition on the serum CrossLaps ${ }^{\mathrm{TM}}$ response to essential amino acidswhey protein supplements. The results are means SEM [absolute values e) and percent from baseline $\mathrm{f}$ )] and were obtained after 1,2 and 4 weeks of nutritional supplements containing $20 \mathrm{~g}$ of protein ( $15 \mathrm{~g}$ whey protein and $5 \mathrm{~g}$ of essential amino acids) without zinc (e: closed squares; f: stippled columns) or with zinc (e: open squares; f: open columns). Untreated controls are represented by triangles (e) and filled columns (f). $* \mathrm{p}<0.05$, $* * \mathrm{p}<$ 0.005: ANOVA for repeated measures; it showed a significant difference between zinc supplemented and the unsupplemented group. $* \mathrm{p}<0.05, * * \mathrm{p}<0.01$ 
Table 2

Changes in Biochemical Variables

\begin{tabular}{|c|c|c|c|c|c|c|}
\hline & Normal Range & Group & D0 & D7 & D14 & D28 \\
\hline Zinc $(\mu \mathrm{mol} / \mathrm{l})$ & $10.0-23.0$ & prot $+z^{1}$ & $12.9 \pm 0.8$ & $13.5 \pm 0.4(+29.0 \%)$ & $14.5 \pm 1.2(+38.4 \%)$ & $16.0 \pm 0.9(+57.5 \%)$ \\
\hline & & $\operatorname{prot}^{2}$ & $14.1 \pm 2.7$ & $13.4 \pm 2.4(-4.4 \%)$ & $13.3 \pm 2.5(-6.5 \%)$ & $14.4 \pm 3.1(+3.6 \%)$ \\
\hline & & untreated ${ }^{3}$ & NA & NA & $\mathrm{NA}$ & NA \\
\hline & & prot & $73.3 \pm 8.3$ & $86.6 \pm 10.1(+22.4 \%)$ & $106.1 \pm 21.5(+38.7 \%)$ & $107.8 \# \# \pm 15.5(+45.8 \%)$ \\
\hline & & untreated & $91.4 \pm 21.5$ & NA & NA & $54.8 \pm 16.8(-16.8 \%)$ \\
\hline \multirow{2}{*}{ IGF-BP3 ( $\mu \mathrm{g} / \mathrm{l})$} & & prot+zn & $2.2 \pm 0.1$ & $2.3 \pm 0.1(+6.5 \%)$ & $2.3 \pm 0.1(+7.0 \%)$ & $2.3 \pm 0.1(+7.1 \%)$ \\
\hline & & prot & $2.1 \pm 0.1$ & $2.2 \pm 0.1(+7.2)$ & $2.3 \pm 0.1(+12.4 \%)$ & $2.4 \pm 0.1(+14.6 \%)$ \\
\hline & & prot & $33.6 \pm 2.7$ & $36.9 \pm 3.3(+13.1 \%)$ & $41.7 \pm 4.5(+23.0 \%)$ & $41.6 \pm 4.2(+21.6 \%)$ \\
\hline & & untreated & $45.4 \pm 8.0$ & NA & NA & $26.8 \pm 7.2(-8.3 \%)$ \\
\hline \multirow[t]{3}{*}{ Osteocalcin $(\mu \mathrm{g} / \mathrm{l})$} & $8.0-40.0$ & prot+zn & $23.7 \pm 1.7$ & $25.3 \pm 2.2(+12.8 \%)$ & $27.3 \pm 2.4(+18.3 \%)$ & $25.8 \pm 2.7(+16.4 \%)$ \\
\hline & & prot & $25.4 \pm 1.7$ & $28.4 \pm 2.2(+6.0 \%)$ & $30.8 \pm 2.4(+21.4 \%)$ & $31.6 \pm 3.4(+21.5 \%)$ \\
\hline & & untreated & $27.4 \pm 1.6$ & NA & NA & $30.0 \pm 2.3(+3.8 \%)$ \\
\hline \multirow[t]{3}{*}{ Crosslaps TM (ng/ml) } & $0.50-0.92$ & prot+zn & $0.56 \pm 0.04$ & $0.5 \pm 0.04(-10.3 \%) \neq$ & $0.46 * \pm 0.04(-20.1 \%)$ & $0.41 * * \pm 0.04(-21.5 \%)$ \\
\hline & & prot & $0.60 \pm 0.05$ & $0.57 \pm 0.04(+3.9 \%)$ & $0.60 \pm 0.04(+6.29 \%)$ & $0.64 \pm 0.06(+6.1 \%)$ \\
\hline & & untreated & $0.43 \pm 0.07$ & NA & NA & $0.68 \pm 0.02(+74.7 \%)$ \\
\hline & & untreated & $67.6 \pm 12.4$ & NA & NA & $70.0 \pm 11.5(+20.5 \%)$ \\
\hline Calcitriol $(\mathrm{pmol} / /)^{\mathrm{b}}$ & $40.0-140.0$ & prot+zn & $90.4 \pm 9.7$ & NA & NA & $92.1 \pm 6.6(+17.4 \%)$ \\
\hline & & prot & $75.0 \pm 8.1$ & NA & NA & $88.1 \pm 6.8(+25.5 \%)$ \\
\hline & & untreated & NA & NA & NA & NA \\
\hline
\end{tabular}

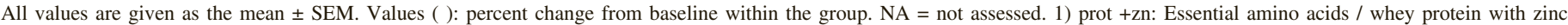

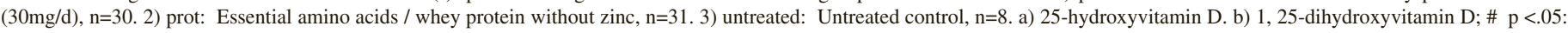

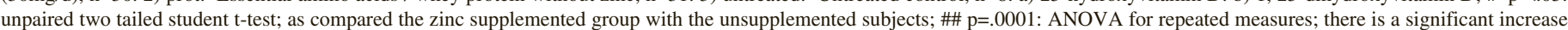

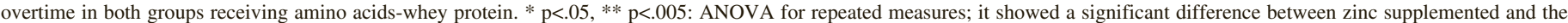

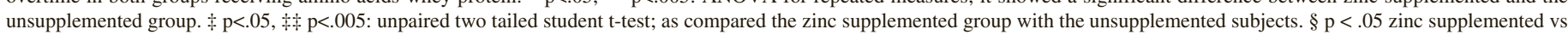
unsupplemented.

\section{Effects of zinc and / or essential amino acids-whey protein supplements on biochemical markers of bone remodeling and on calcium-phosphate metabolism}

In response to essential amino acids-whey protein supplements, the bone formation marker osteocalcin increased in the two supplemented groups, reaching a maximum by the second week of supplementation (Fig. 2). There was no change in untreated controls. Zinc did not affect the osteocalcin response to protein repletion.

The bone resorption marker CrossLaps ${ }^{\mathrm{TM}}$ increased in the untreated controls, remained stable in the essential amino acidswhey protein group, and significantly decreased upon zinc supplementation (Fig. 2), with significant differences between the two supplemented groups, detectable at just one week of supplementation.

Although the increase of dietary protein intake may improve calcium intestinal absorption (42), plasma levels of parathyroid hormone, 25-hydroxyvitamin D3 and 1,25-dihydroxyvitamin D3 (Table 2), calcium (total, ionised and protein-adjusted), phosphate, proteins and creatinine (data not shown) did not change during the study and did not differ between the two groups who received similar amount of protein and calcium. The renal handling of calcium or of phosphate was also not influenced.

\section{Effects of zinc and/or essential amino acids-whey protein} supplements on functional performances

There was no difference in the dietary intakes recorded by the dietician between the two groups and at the end of the study. The number of kilocalories was, in the supplemented group with additional zinc, $1237 \pm 126$ at the beginning and $1096 \pm 133$ at the end, and in the other protein supplemented group $1219 \pm 280$ and $1292 \pm 350$, respectively. There was a small but not significant decrease in spontaneous protein intake in the supplemented group with additional zinc at the end of the trial but without any difference comparing the two supplemented groups.

Functional performances were evaluated by recording the Activity of Daily Living score (38). This index slightly improved upon essential amino acids-whey protein supplements, irrespective of zinc addition (Table 3). However, in a prespecified subgroup with baseline serum albumin lower than $30 \mathrm{~g} / \mathrm{l}$, zinc significantly increased this response. Hospital stay averaged $42.5 \pm 3.5$ days and was not different among the groups (Table 3). 


\section{JNHA: NUTRITION}

Table 3

Changes at 28 Days in Functional Performances Variables

\begin{tabular}{|c|c|c|c|c|c|c|c|c|}
\hline & & & $\begin{array}{l}\text { EAA / whey protein } \\
\text { with zinc }(30 \mathrm{mg} / \mathrm{d})\end{array}$ & & & $\begin{array}{l}\text { / whey protein } \\
\text { without zinc }\end{array}$ & & Untreated controls \\
\hline & & $\begin{array}{c}\text { All } \\
\mathrm{n}=30\end{array}$ & $\begin{array}{c}\text { alb }<30 \mathrm{~g} / \mathrm{l} \\
\mathrm{n}=10\end{array}$ & $\begin{array}{c}\text { alb }>30 g / 1 \\
n=20\end{array}$ & $\begin{array}{c}\text { All } \\
n=31\end{array}$ & $\begin{array}{c}\text { alb }<30 \mathrm{~g} / \mathrm{l} \\
\mathrm{n}=13\end{array}$ & $\begin{array}{c}\text { alb }>30 g / 1 \\
n=18\end{array}$ & $\mathrm{n}=8$ \\
\hline \multirow[t]{3}{*}{ ADL score ${ }^{a}$} & D0 & $10.6(0.5)$ & $11.6(1.0)$ & $10.1(0.6)$ & $10.5(0.5)$ & $10.2(0.7)$ & $10.8(0.7)$ & NA \\
\hline & D28 & $7.7(0.3)$ & $7.6(0.6)$ & $7.8(0.4)$ & $8.4(0.6)$ & $8.6(0.9)$ & $8.1(0.8)$ & NA \\
\hline & Percent change & $-27.0(3.1)^{* *}$ & $-25.7(8.1)^{*}$ & $-27.4(3.2)$ & $-18.3(4.5)^{* *}$ & $-11.9(6.5)$ & $-24.7(5.5)$ & NA \\
\hline \multirow[t]{3}{*}{$\mathrm{BMI}^{\mathrm{b}}$} & D0 & $22.1(1.1)$ & $21.8(1.3)$ & $22.2(1.5)$ & $21.7(0.7)$ & $21.7(1.4)$ & $21.8(0.9)$ & $26.2(1.0) \#$ \\
\hline & D28 & $22.7(2.1)$ & $22.5(2.1)$ & $22.8(3.2)$ & $21.4(1.2)$ & $21.4(1.9)$ & $21.5(1.5)$ & $25.7(1.0)$ \\
\hline & Percent change & $-0.5(0.7)$ & $-0.8(1.3)$ & $-0.4(0.9)$ & $-1.3(0.8)$ & $-1.5(0.8)$ & $1.1(1.6)$ & $-1.9(1.5)$ \\
\hline Hospital stay (day) & & $45.4(5.7)$ & $52.1(7.2)$ & $42.1(7.8)$ & $39.7(4.3)$ & $48.2(9.0)$ & $33.7(3.4)$ & $39.3(8.8)$ \\
\hline
\end{tabular}

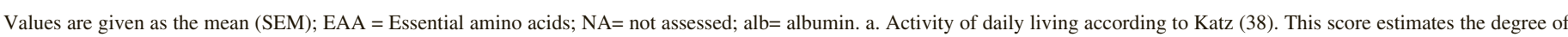

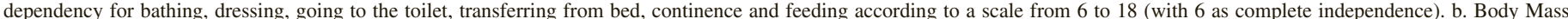

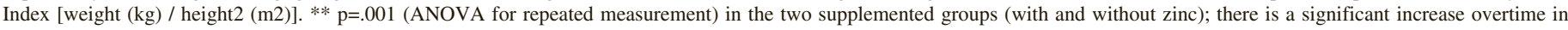

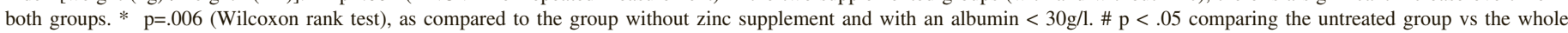
supplemented group

\section{Discussion}

In the present study, we investigated whether the addition of zinc, which is known to influence IGF-I production, is able to modify the IGF-I response to essential amino acids-whey protein supplements in undernourished elderly patients. The results indicate that a zinc supplement significantly accelerated IGF-I recovery and reduced the serum levels of a biochemical marker of bone resorption. Activities of daily living were significantly improved by zinc supplementation in the subgroup of patients with lower serum albumin.

Protein malnutrition is often observed in the elderly and is associated with a large series of morbidities, including osteoporosis and impaired post-fracture recovery $(3,8)$. Previous randomized controlled trials in recent hip fracture patients have demonstrated that a simple oral casein protein supplement given for periods between 5 weeks and 6 months, that just corrected protein undernutrition, not only improved fracture outcome (19-21,43), but also attenuated proximal femur bone loss (21). These findings were associated with increased serum IGF-I levels (21). Our study confirms the beneficial effects of oral protein supplements on IGF-I activity in the non fractured frail elderly, with a rapid response detectable by just one week of supplementation. This is in agreement with previous studies that showed 5 weeks of protein supplementation was able to significantly improve the outcome after hip fracture $(19,20)$. The type of supplements we used in the present study were based on observations of animal experiments, in which essential amino acid supplements were able to increase bone strength, to improve microarchitecture and intrinsic bone tissue quality (13). This was observed in adult rats receiving an isocaloric low protein diet, a situation reminiscent of the conditions of the frail elderly investigated in the current trial.

Zinc insufficiency is highly common in the elderly and may contribute to a frailty syndrome, possibly through an effect on IGF-I production and/or action $(24,27,28)$. We thus performed the present study in order to assess the hypothesis that zinc could magnify the circulating levels and actions of IGF-I and the functional response to protein repletion. Plasma zinc measurements may not be the reflection of body stores because most of the body zinc stores are intracellular. Hence, mild zinc insufficiency can occur with low but still in the normal range plasma levels. At baseline, both groups had a zinc serum concentration at the lower limit of normal range. After four weeks, it remained stable in the non supplemented group, whilst an increase of close to $60 \%$ was observed in the group receiving zinc (Table 2). Our results indicate that the increase in serum IGF-I levels induced by protein supplements was accelerated, with a significant difference detectable after only one week of zinc addition. This could represent a clinically relevant advantage, since the potential benefits of correcting low IGF-I concentration could be achieved at a very early stage of intervention. A rapid improvement would be particularly desirable in the phase of recovery after surgery or in the rehabilitation phase of undernourished elderly. By 4 weeks of protein supplements, however, there was no further advantage of zinc supplementation.

Previous studies in humans and in animals have demonstrated that protein deficiency is associated with an increased bone loss and decreased bone strength $(3,12)$. These modifications of bone strength are the results of a markedly increased bone resorption and decreased bone formation. In the present study, untreated controls showed an increase in the bone resorption marker, CrossLaps ${ }^{\mathrm{TM}}$, during the 4 -week observation period, whereas the values remained stable in the group receiving the essential amino acids-whey protein supplements. Zinc addition was associated with a significant reduction of the bone resorption marker. At the present time, we have no argument in favor of a direct or indirect effect of zinc on bone turnover. In vitro experiments have shown some inhibition of bone resorption by zinc $(32,34)$. However, our experimental design does not allow one to selectively assess the effects of zinc supplements on bone remodeling, since there 


\section{ZINC AND PROTEIN SUPPLEMENTS}

was an interaction with protein repletion. Additional studies are still required to confirm this hypothesis. In preclinical studies, essential amino acids supplements decreased bone resorption in rats fed an isocaloric low protein diet (13). The mechanisms of this protein effect on bone resorption have not yet been elucidated. IGF-I is unlikely to be the only factor involved since this growth factor acts to increase bone remodeling, as demonstrated by significant increases in osteocalcin, and is involved in osteoclastogenesis regulation (44). The patients enrolled in the study were clearly undernourished as indicated by the mini nutritional assessment score (37) and the low values of serum albumin and IGF-I. Despite a strict randomization procedure, there was a small difference in vitamin $\mathrm{D}$ status at baseline between the zinc group and the controls. There is likely to be a link between vitamin $\mathrm{D}$ and IGF-I $(45,46)$; however, in our study we didn't find any correlation between IGF-I level and vitamin D (data not shown). This is very unlikely to explain the IGF-I response to zinc. Although the present study was underpowered to detect significant changes in functional performances, we were able to observe that in the prespecified subgroup with baseline albumin below $30 \mathrm{~g} / 1$, zinc addition was associated with a more favorable evolution of ADL score.

In conclusion, the present study has shown that protein supplements (including whey protein and essential amino acids) increase serum IGF-I and a bone formation marker in undernourished elderly patients. Furthermore, we have demonstrated that the addition of zinc to the protein supplements accelerates the IGF-I response, and this is accompanied by an inhibition of bone resorption. This nutritional combination could be beneficial in the frail elderly at risk for osteoporotic fracture.

Acknowledgments: We are indebted to the nurses and to the medical staff of the Geneva geriatric hospital for their help in the patients' recruitment and investigation. We thank Mrs Sonja Clement for her invaluable contribution in data collection, Dr Jean-Daniel Graf, $\mathrm{PhD}$, Dr Nouri Mensi and Dr Laszlo Vadas, $\mathrm{PhD}$, for the biochemical determination, Mrs Marianne Perez for secretarial assistance and Dr Tara C. Brennan, PhD, for the careful reading and corrections. This study was supported by Novartis-Nutrition (Berne, Switzerland) and by the National Science Research Foundation (grant No. 3200B0100714).

\section{Author Contributions:}

AR was in charge of recruiting the patients, collecting, analyzing and interpreting the data, and of manuscript preparation

PA contributed to study concept and design, data collection, analysis and interpretation, and to manuscript preparation

SGB participated in patient recruitment and data collection

RR contributed to study concept and design, data collection, analysis and interpretation, and to manuscript preparation

Sponsor's Role: This project was supported by a grant from Novartis Consumer Heath, Berne, Switzerland, which provided the nutritional supplements and funds for the biochemical determinations. The sponsor did not interfere with the study design, data collection and interpretation, nor with manuscript preparation.

Financial disclosure: Patrick Ammann and René Rizzoli have received grants from industry entities for preclinical research projects and/or multicenter clinical trials. They belong to the speaker bureau of the major companies with interest in metabolic bone diseases. They also belong to some scientific advisory boards of the same companies. René Rizzoli acts as consultant for Danone Company, Paris, France and Amgen Company, Zug, Switzerland.

\section{References}

1. Sullivan D H, Sun S, Walls R C. Protein-energy undernutrition among elderly hospitalized patients: a prospective study. Jama 1999; 281: 2013-2019.

2. Corish C A, Kennedy N P. Protein-energy undernutrition in hospital in-patients. Br J Nutr 2000; 83: 575-591.

3. Rizzoli R, Bonjour J P. Dietary protein and bone health. J Bone Miner Res 2004; 19: 527-531.

4. Geinoz G, Rapin C H, Rizzoli R, Kraemer R, Buchs B, Slosman D, Michel J P, Bonjour J P. Relationship between bone mineral density and dietary intakes in the elderly. Osteoporos Int 1993; 3: 242-248.

5. Hannan M T, Tucker K L, Dawson-Hughes B, Cupples L A, Felson D T, Kiel D P. Effect of dietary protein on bone loss in elderly men and women: the Framingham Osteoporosis Study. J Bone Miner Res 2000; 15: 2504-2512.

6. Promislow J H, Goodman-Gruen D, Slymen D J, Barrett-Connor E. Protein consumption and bone mineral density in the elderly : the Rancho Bernardo Study. Am J Epidemiol 2002; 155: 636-644.

7. Rapuri P B, Gallagher J C, Haynatzka V. Protein intake: effects on bone mineral density and the rate of bone loss in elderly women. Am J Clin Nutr 2003; 77: 15171525 .

8. Rizzoli R, Ammann P, Chevalley T, Bonjour J P. Protein intake and bone disorders in the elderly. Joint Bone Spine 2001; 68: 383-392.

9. Thissen J P, Ketelslegers J M, Underwood L E. Nutritional regulation of the insulinlike growth factors. Endocr Rev 1994; 15: 80-101.

10. Bonjour J P, Schurch M A, Chevalley T, Ammann P, Rizzoli R. Protein intake, IGF1 and osteoporosis. Osteoporos Int 1997; 7 (Suppl 3): S36-42.

11. Bourrin S, Toromanoff A, Ammann P, Bonjour J P, Rizzoli R. Dietary protein deficiency induces osteoporosis in aged male rats. J Bone Miner Res 2000; 15: 15551563.

12. Ammann P, Bourrin S, Bonjour J P, Meyer J M, Rizzoli R. Protein undernutritioninduced bone loss is associated with decreased IGF-I levels and estrogen deficiency. J Bone Miner Res 2000; 15: 683-690.

13. Ammann P, Laib A, Bonjour J P, Meyer J M, Ruegsegger P, Rizzoli R. Dietary essential amino acid supplements increase bone strength by influencing bone mass and bone microarchitecture in ovariectomized adult rats fed an isocaloric low-protein diet. J Bone Miner Res 2002; 17: 1264-1272.

14. Hengsberger S, Ammann P, Legros B, Rizzoli R, Zysset P. Intrinsic bone tissue properties in adult rat vertebrae: modulation by dietary protein. Bone $2005 ; 36: 134-$ 141.

15. Ammann P, Rizzoli R. Bone strength and its determinants. Osteoporos Int 2003; 14 Suppl 3: S13-18.

16. Bourrin S, Ammann P, Bonjour J P, Rizzoli R. Dietary protein restriction lowers plasma insulin-like growth factor I (IGF-I), impairs cortical bone formation, and induces osteoblastic resistance to IGF-I in adult female rats. Endocrinology 2000; 141: 3149-3155.

17. Ammann P, Rodriguez L, Aubert M L, Bonjour J P, Rizzoli R. Growth hormone $(\mathrm{GH})$ decreases bone mineral mass and bone strength in adult female rats fed a low protein diet. J Bone Miner Res 2001; 16 (Suppl. 1): S294.

18. Ammann P, Gabay C, Palmer G, Garcia I, Rizzoli R. Tumor necrosis factor alpha but not interleukine-1 is involved in protein undernutrition-induced bone resorption. J Bone Miner Res 2002; 17 (Suppl. 1): S205.

19. Delmi M, Rapin C H, Bengoa J M, Delmas P D, Vasey H, Bonjour J P. Dietary supplementation in elderly patients with fractured neck of the femur. Lancet 1990; 335: 1013-1016.

20. Tkatch L, Rapin C H, Rizzoli R, Slosman D, Nydegger V, Vasey H, Bonjour J P. Benefits of oral protein supplementation in elderly patients with fracture of the proximal femur. J Am Coll Nutr 1992; 11: 519-525.

21. Schurch M A, Rizzoli R, Slosman D, Vadas L, Vergnaud P, Bonjour J P. Protein supplements increase serum insulin-like growth factor-I levels and attenuate proximal femur bone loss in patients with recent hip fracture. A randomized, double-blind, placebo-controlled trial. Ann Intern Med 1998; 128: 801-809.

22. Hampson G, Martin F C, Moffat K, Vaja S, Sankaralingam S, Cheung J, Blake G M, Fogelman I. Effects of dietary improvement on bone metabolism in elderly underweight women with osteoporosis: a randomised controlled trial. Osteoporos Int 2003; $14: 750-756$.

23. Prasad A S. Clinical manifestations of zinc deficiency. Annu Rev Nutr 1985; 5: 341363.

24. Devine A, Rosen C, Mohan S, Baylink D, Prince R L. Effects of zinc and other nutritional factors on insulin-like growth factor I and insulin-like growth factor binding proteins in postmenopausal women. Am J Clin Nutr 1998; 68: 200-206.

25. Imamoglu S, Bereket A, Turan S, Taga Y, Haklar G. Effect of zinc supplementation on growth hormone secretion, IGF-I, IGFBP-3, somatomedin generation, alkaline phosphatase, osteocalcin and growth in prepubertal children with idiopathic short stature. J Pediatr Endocrinol Metab 2005; 18: 69-74.

26. Ninh N X, Thissen J P, Collette L, Gerard G, Khoi H H, Ketelslegers J M. Zinc supplementation increases growth and circulating insulin-like growth factor I (IGF-I) in growth-retarded Vietnamese children. Am J Clin Nutr 1996; 63: 514-519. 


\section{JNHA: NUTRITION}

27. Ninh N X, Maiter D, Verniers J, Lause P, Ketelslegers J M, Thissen J P. Failure of exogenous IGF-I to restore normal growth in rats submitted to dietary zinc deprivation. J Endocrinol 1998; 159: 211-217.

28. Ninh N X, Thissen J P, Maiter D, Adam E, Mulumba N, Ketelslegers J M. Reduced liver insulin-like growth factor-I gene expression in young zinc-deprived rats is associated with a decrease in liver growth hormone $(\mathrm{GH})$ receptors and serum $\mathrm{GH}-$ binding protein. J Endocrinol 1995; 144: 449-456.

29. Brown K H, Peerson J M, Rivera J, Allen L H. Effect of supplemental zinc on the growth and serum zinc concentrations of prepubertal children: a meta-analysis of randomized controlled trials. Am J Clin Nutr 2002; 75: 1062-1071.

30. Darnton-Hill I, Webb P, Harvey P W, Hunt J M, Dalmiya N, Chopra M, Ball M J, Bloem M W, de Benoist B. Micronutrient deficiencies and gender: social and economic costs. Am J Clin Nutr 2005; 81: 1198S-1205S.

31. Pepersack T, Rotsaert P, Benoit F, Willems D, Fuss M, Bourdoux P, Duchateau J. Prevalence of zinc deficiency and its clinical relevance among hospitalised elderly. Arch Gerontol Geriatr 2001; 33: 243-253.

32. Yamaguchi M, Uchiyama S. Regucalcin stimulates osteoclast-like cell formation in mouse marrow cultures. J Cell Biochem 2005; 94: 794-803.

33. Holloway W R, Collier F M, Herbst R E, Hodge J M, Nicholson G C. Osteoblastmediated effects of zinc on isolated rat osteoclasts: inhibition of bone resorption and enhancement of osteoclast number. Bone 1996; 19: 137-142.

34. Moonga B S, Dempster D W. Zinc is a potent inhibitor of osteoclastic bone resorption in vitro. J Bone Miner Res 1995; 10: 453-457.

35. Calhoun N R, Smith J C, Jr., Becker K L. The role of zinc in bone metabolism. Clin Orthop Relat Res 1974: 212-234.

36. Ma Z J, Yamaguchi M. Alternation in bone components with increasing age of newborn rats: role of zinc in bone growth. J Bone Miner Metab 2000; 18: 264-270.

37. Vellas B, Guigoz Y, Garry P J, Nourhashemi F, Bennahum D, Lauque S, Albarede J L. The Mini Nutritional Assessment (MNA) and its use in grading the nutritional state of elderly patients. Nutrition 1999; 15: 116-122.
38. Katz S, Ford A B, Moskowitz R W, Jackson B A, Jaffe M W. Studies of Illness in the Aged. The Index of Adl: A Standardized Measure of Biological and Psychosocial Function. Jama 1963; 185: 914-919.

39. Bijvoet O L. Relation of plasma phosphate concentration to renal tubular reabsorption of phosphate. Clin Sci 1969; 37: 23-36.

40. Bonjour J P, Philippe J, Guelpa G, Bisetti A, Rizzoli R, Jung A, Rosini S, Kanis J A. Bone and renal components in hypercalcemia of malignancy and responses to a single infusion of clodronate. Bone 1988; 9: 123-130.

41. Amin S, Riggs B L, Atkinson E J, Oberg A L, Melton L J, 3rd, Khosla S. A potentially deleterious role of IGFBP-2 on bone density in aging men and women. J Bone Miner Res 2004; 19: 1075-1083.

42. Kerstetter J E, O'Brien K O, Insogna K L. Dietary protein, calcium metabolism, and skeletal homeostasis revisited. Am J Clin Nutr 2003; 78: 584S-592S.

43. Avenell A, Handoll $\mathrm{H} \mathrm{H}$. A systematic review of protein and energy supplementation for hip fracture aftercare in older people. Eur J Clin Nutr 2003; 57: 895-903.

44. Wang Y, Nishida S, Elalieh H Z, Long R K, Halloran B P, Bikle D D. Role of IGFsignaling in regulating osteoclastogenesis. J Bone Miner Res 2006; 21: 1350-1358.

45. Gomez J M. The role of insulin-like growth factor I components in the regulation of vitamin D. Curr Pharm Biotechnol 2006; 7: 125-132.

46. Soliman A T, Al Khalaf F, Alhemaidi N, Al Ali M, Al Zyoud M, Yakoot K. Linear growth in relation to the circulating concentrations of insulin-like growth factor I, parathyroid hormone, and 25-hydroxy vitamin $\mathrm{D}$ in children with nutritional rickets before and after treatment: endocrine adaptation to vitamin D deficiency. Metabolism 2008; 57: 95-102. 